\title{
Morphometric Analysis of Katra Watershed of Eastern Ghats: A GIS Approach
}

\author{
Partha Pratim Adhikary" and Ch. Jyotiprava Dash \\ ICAR Indian Institute of Soil and Water Conservation, Research Centre, Koraput, \\ Odisha - 763002, India \\ *Corresponding author
}

\section{A B S T R A C T}

Watershed is generally considered as the smallest unit to get hydrological response of any developmental activity. To work out a comprehensive development plan for optimum use

\section{Keywords}

Morphomety, Watershed, GIS, Eastern Ghats, Koraput

Article Info

Accepted:

16 February 2018

Available Online:

10 March 2018 of natural resources the study of watershed characteristics is necessary. Watershed characteristics can be understood from the morphometric analysis and which can be better analyzed by GIS. The aim of the present study is to understand the morphometric characteristics of Katra watershed of Koraput, Odisha, situated in part of Eastern Ghats, an ecologically sensitive region using GIS. The drainage area of Katra watershed is $34 \mathrm{~km}^{2}$ and the drainage pattern is dendritic to sub-dendritic. The slope of the watershed varied from 0 to $82 \%$ and the slope variation is chiefly controlled by the local geomorphology and erosion cycles. The watershed was classified as a forth order drainage basin and the controlling factors of the stream orders are physiography, rainfall, local lithology and structure. The lower order streams are mostly dominating in the watershed. Lithological, structural and geomorphological expression of the watershed controls the flow direction of the entire drainage network. The increase in stream length ratio from lower to higher order is an indication of geomorphically mature watershed. The work will be the input to evaluate the basin hydrology, water resources, and input and output components in the hydrology cycle.

\section{Introduction}

Morphometric analysis is the mathematical analysis of the earth's surface configuration including its shape, size, landforms dimension etc (Clarke, 1996). It describes the basin geometry quantitatively and analyse the geology, geomorphology, slope, rock hardness and other structural controls of drainage basin (Strahler, 1964). Thereby, it is important for hydrological investigations of any watershed for its better management (Magesh et al., 2011). Development of a drainage system and the spatio-temporal pattern of river flow are governed by the geology, geomorphology, soil, land use and other structural components of the area through which it flows. At the basin and watershed scale, geology, relief and climate mainly determine the functions of a river system (Mesa, 2006). The geomorphologic features of the catchment area control the dynamic nature of runoff, 
which is very sensitive to the morphometric characteristics of the watershed (Rudraiah et al., 2008). Detailed morphometric analysis of a watershed can give us some insight about how the landform characteristics can be manipulated by drainage morphometry. This analysis at the watershed scale can tell about the formation and development of watersheds as all hydrologic and geomorphic processes occur within the watershed.

Geographical Information System (GIS) is a technique commonly used for assessing the morphometric parameters of the watersheds and drainage basins because of their flexibility to manipulate the spatial data, particularly related to parameters that vary space and time within a watershed for their better management (Sreedevi et al., 2009; Magesh et al., 2011; Pareta and Pareta, 2011; Magesh et al., 2013). Several researchers used the morphometric analysis as a tool to achieve optimum use of natural resources in a watershed and to identify the incidence of any natural disaster in a watershed or basin. Sreedevi et al., (2005) used morphometric analysis to determine the groundwater potential zones in a semi-arid watershed in India. Pankaj and Kumar (2009) used GIS and monphometric tools to analyze the landslide incidence of Song river of Dehradun, Uttarakhand.

In basin as well as watershed scale, the drainage network is the manifestation of combined influence of climate, soil, geology and geomorphology (Mesa, 2006; Wilson et al., 2012; Magesh and Chandrasekar, 2012).

Therefore, morphometric analysis of a watershed is the prerequisite to comprehend the processes involved to develop a landfom within a watershed (Magesh et al., 2013). The linear, aerial and relief aspects of watershed can be the relics to the researchers to characterize the watershed and prioritize the developmental works for proper utilization of natural resource of any watershed. Keeping these things in mind an attempt has been made to assess and evaluate various morphometric parameters of Katra watershed of Koraput district using RS and GIS where the linear, areal and relief related morphometric parameters were analyzed for planning and development of the watershed.

\section{Materials and Methods}

\section{Study area}

Katra watershed of Semiliguda block of Koraput district is an important watershed where the developmental activities are getting momentum in recent times. It is situated between $18^{\circ} 43^{\prime}$ to $18^{\circ} 48^{\prime} \mathrm{N}$ and $82^{\circ} 51^{\prime} 82^{\circ} 58^{\prime}$ $\mathrm{E}$, having total geographical area of 33.52 $\mathrm{km}^{2}$.

Katra is the main river of the watershed which drains to the Kolab River $12.67 \mathrm{~km}$ away from the origin. There is no main tributary of the Katra river, but some small tributaries pouring in to the river and ultimately drains to the Kolab river (Fig. 1). This study area falls in Survey of India toposheets numbers E44K13 and E44K14 (1:50,000). National Aluminium Company Limited (NALCO) is situated within the watershed and exerted its effect on the land use and hydrology of the watershed.

The climate of the study area is warm and humid with annual mean maximum and minimum temperatures of $35.8^{\circ} \mathrm{C}$ and $7.6^{\circ} \mathrm{C}$, respectively. The mean rainfall of the district is $1452 \mathrm{~mm}$ (Adhikary et al., 2015). The area experiences a special monsoon features. The occurrence of rain invariably accompanies with intense and short duration storms. Thus, high intense storms during rainy season generate enormous runoff, which passes through the jhola (modified stream) beds and thus, causes heavy soil loss. 


\section{Soil and geomorpholgy}

The type of soils influences the amount of water, which will be absorbed by the soil. The soil character also determines the amount of silt, which will be washed down in water harvesting structures and the valleys below. The study area possesses lithology mainly composed of shale, slate and sand stones showing faults and fissures, which makes the area prone to soil erosion. Based on the United State Department of Agriculture (USDA) soil taxonomy, the soils have been identified as Alfisols and Inceptisols. Soil depth and soil texture vary with the topography and become less favourable for cultivation with increasing slope steepness. The hills and hill slopes are mostly dominated by light yellow to brown soils, whereas red sandy to loamy soils are found in the foothills and uplands. The soils are coarse textured ranging from sandy loam to sandy clay loams with low water retention capacity. With an increase of slope steepness the soil depth is decreasing and the amount of gravels is rising. On hillock patches rock exposure occurs. In gently sloping areas the soil depth is deep to very deep.

\section{Land use}

The land use affects rates of runoff infiltration, types and quality of the vegetation cover. The study area is dominated by agriculture with shrubs at the hill tops. There are some plantations prevailed in the watershed (Fig. 2). Due to poor organic matter content, steep slopes and unsuitable landuse patterns, water erosion is a serious problem in the area. However due to human interference the vegetation shows severe signs of degradation and forest cover has declined within the last decades. Shifting cultivation, which is prevalent in this area, has become menace for generation of the secondary forest. Sloping uplands and agriculture lands are completely barren due to over exploitation of the available natural resources. Agricultural practices extend from valley bottom to hilltop, with variety of cropping systems and management practices. Finger millet, paddy, niger, maize, lentil, potato and zinger are the main crops. During the winter months vegetables are grown in the fields. Most of the area falls under rainfed mixed farming and the dependency on rainfall is very high.

\section{GIS and calculation}

For morphometric analysis of the watershed, the base map and the drainage network map of the watershed were prepared using Survey of India topographic sheets on the 1:50,000 scale with $20 \mathrm{~m}$ contour interval. The watershed was demarcated based on the elevation, slope and outlet point. It was digitized in the ArcGIS 9.3 software and the morphometric parameters such as stream length, stream frequency, length of overland flow, bifurcation ratio, drainage texture, drainage density, basin shape, form factor, circulatory ratio, elongation ratio, relief ratio were computed using standard methods and formulae (Horton, 1932; Horton, 1945; Miller, 1953; Schumn, 1956; Strahler, 1957).

\section{Results and Discussion}

The morphometric parameters of Katra watershed have been studied in detail and found that the total drainage area is $34 \mathrm{~km}^{2}$. The drainage pattern is dendritic in nature and it is influenced by the general topography of the area. The drainage pattern shows the influence of slope and lithology. Dendritic pattern is most common pattern found in a drainage basin composed of fairly homogeneous rock with no control of the underlying geologic structure.

\section{Average slope of the watershed (S)}

Average slope of a watershed can predict the erodibility of a watershed Wenthworth (1930). Higher the degree of slopes, higher is the 
erosion, keeping all other things constant. Here the value of average slope of the watershed was $32.9 \%$. The slope map of the watershed is presented in Figure 3. The slope ranged between 0 and $82 \%$. Majority of the area is under gentle slope, but few steep hills are associated with the watershed and increased the range.

\section{Linear aspect}

\section{Stream order $(\mathrm{Su})$}

Stream ordering is the fundamental to any quantitative analysis of drainage basin. Higher the stream order, higher is the watershed area. In the present study, the orders of streams are $1^{\text {st }}$ order, $2^{\text {nd }}$ order, $3^{\text {rd }}$ order and $4^{\text {th }}$ order thereby the watershed is designated as $4^{\text {th }}$ order watershed. The law of stream number (Horton, 1945) and the law of stream length (Horton, 1932) were also substantiated by the stream network of the present watershed.

\section{Stream number $(\mathbf{N u})$}

The number of the stream segments of any particular order is known as stream number. Horton (1945) states that the stream order and the stream number of any particular order are geometrically inversely related.

Here the numbers of stream of different order are as follows: $1^{\text {st }}$ order is $132,2^{\text {nd }}$ order is 34 , $3^{\text {rd }}$ order is 7 and the $4^{\text {th }}$ order stream is 1 . More first order streams are an indicator of sudden heavy runoff load to the down streams (Magesh et al., 2013).

\section{Stream length (Lu)}

The total stream lengths of the Katra watershed under various orders were computed with the help of SOI topographical sheets and GIS. Geometrical similarity used to maintain in the watershed of increasing order
(Strahler, 1964). Here we computed the value as per Horton's law that is $111 \mathrm{~km}$ (Table 1). Streams with relatively short lengths represent the areas having finer texture with steep slopes, whereas longer lengths of stream are generally indicative of gentle slopes (Strahler, 1964).

\section{Mean stream length (Lum)}

Mean Stream length can be calculated by dividing the total stream length of a particular order by total stream number of that order. The size of the watershed surface which contributes to the drainage network can be revealed from the Lum (Strahler, 1964).

In this study the mean stream length varied from 533 to $9458 \mathrm{~m}$ with average value for the whole watershed was $636 \mathrm{~m}$ (Table 1). In a watershed the Lum of any order is higher than that of the lower order and lower than that of the higher order. The size and topography of watershed govern the value of Lum which differ with respect to different watersheds (Magesh et al., 2013).

\section{Stream length ratio (Lurm)}

Horton (1945) states that the stream length ratio is the ratio of the average length segment of any order to the average length segment of the next lower order, which, in a watershed, remains constant for the successive orders. In the present work, stream length ratios were 1.3-9.1 and thereby showed their dependency on slope and topography. Similar observations are noted in Aiyar basin by Wilson et al., (2012) and in Bharathapuza basin by Magesh et al., (2013).

\section{Bifurcation ratio $(\mathbf{R b})$}

The bifurcation ratio is the ratio of the number of the streams of given order to the number of streams in the next higher order (Horton, 
1945). It is a dimensionless property. Here in this work bifurcation ratio was in between 3.88-7.

\section{Weighted mean bifurcation ratio (Rbwm)}

To get a representative bifurcation number, Strahler (1964) approached weighted mean bifurcation ratio. It can be calculated by multiplying the bifurcation ratio of a pair order by the total numbers of streams involved in the ratio. The mean of the sum of these values will be the Rbwm. In the present study the value of Rbwm was 4.18. The mean bifurcation ratio of the watershed indicted that the influence of geological structures on the drainage network is negligible (Magesh et al., 2013). The result indicated that the ratio is not same for all the orders because of the variation of geology and lithology in the watershed (Strahler, 1964).

\section{Length of main channel $(\mathrm{Cl})$}

Main channel length is outlet to the channel head along a subjectively defined main channel or more objectively, the length of the longest flow path to the drainage divide. We have computed the main channel length by using ArcGIS-9.3 software, which was 12.64 km (Table 2).

\section{Channel index (Ci) and Valley index (Vi)}

The stream channel was divided into number of segments as suggested by Friend and Sinha (1993) for determination of sinuosity parameter. The measurement of channel length, valley length, and the aerial lengths between outlet and stream start are used for calculation of Channel index, and valley index. For the Katra watershed, the value of channel index was 1.12 and valley index was 1.01. This result was similar to the result obtained by Pande and Moharir (2015) at Shanur river basin of Maharashtra, India.

\section{Rho coefficient ( $\rho)$}

The drainage density and watershed physiography is related to each other through $\rho$ coefficient. It determine the storage capacity of any drainage network and thereby, an index to know the degree of drainage development (Horton, 1945).

This parameter is dependent on climate, geology, land use, geomorphology, and human interventions in any watershed. Rho values of the Katra watershed was 0.33-1.30 and indicated the better water storage capacity of the watershed and induced flood buffering capacity. Pande and Moharir (2015) observed the $\rho$ value of 0.32 at Shanur river basin of Maharashtra.

In another study at Chakrar watershed of Madhya Pradesh, Soni (2016) observed the $\rho$ value of $0.47-0.91$.

\section{Length of the basin ( $\mathrm{Lb})$}

It can be defined as the longest dimension of the basin parallel to the principal drainage line (Schumm, 1956). It is the length of the line from a basin mouth to a point on the perimeter which rests furthest from the outlet. The length of the Katra watershed in accordance with the definition of Schumm (1956) was $11.34 \mathrm{~km}$.

\section{Areal aspect}

\section{Watershed area (A)}

The area of the watershed is very important to determine drainage network and discharge. Total watershed area and total stream length is directly related to each other (Schumm, 1956), and influenced by the contributing areas. In this study the basin area was computed using ArcGIS software and which was found as $33.52 \mathrm{~km}^{2}$ (Table 3). 


\section{Watershed perimeter $(\mathbf{P})$}

Basin perimeter is the outer boundary of the watershed that enclosed its area. The length of the ridge line which separates the watershed can be used as the watershed perimeter. It is also an indicator of watershed size and shape. The basin perimeter was computed by using ArcGIS-9.3 software, and the value was 38.56 $\mathrm{km}$.

\section{Length area relation (Lar)}

For a large number of basins in the USA, the stream length and basin area are related by a simple power function as follows: Lar $=1.4 *$ $\mathrm{A}^{0.6}$ Hack (1957). Using this relation we estimated the length of the Katra watershed and found it as $11.52 \mathrm{~km}$, which is quite same to the length obtained by using GIS technique.

\section{Lemniscate's (k)}

The Lemniscate's value can be used to determine the slope of the watershed. The expression as given by Chorley (1957) as $\mathrm{k}=$ $\mathrm{Lb}^{2} / 4 * \mathrm{~A}$, where, Lb is the basin length $(\mathrm{km})$ and $A$ is the area of the basin $\left(\mathrm{km}^{2}\right)$. The Lemniscate $(\mathrm{k})$ value for the watershed was 3.84, which shows that the maximum inception area comprises by large number of streams of higher order.

\section{Form factor (Ff)}

The ratio of watershed area to square of the basin length is the form factor (Horton, 1932). For a perfectly circular watershed the value of form factor is 0.754. But for all natural watersheds the value will be less than that. Smaller the value, less circular or more elongated the watershed. Short duration high peak flows are common for the watershed with high form factors, whereas elongated watershed with low form factor indicate flow for longer duration. In the present study, the form factor was 0.26 indicating no sudden peak discharge at the outlet. In a watershed study of Madhya Pradesh, Soni (2016) observed the value of Ff varies between 0.170.24 .

\section{Elongation ratio $(\mathbf{R e})$}

The elongation ratio $(\mathrm{Re})$ is the ratio between the diameter of the circle of the same area as the drainage basin and the maximum basin length. A circular basin is more efficient in the discharge of runoff than an elongated basin.

The values of Re vary from 0.6 to 1.0 over a wide variety of climatic and geologic type. In our present study the elongation ratio was 0.57 . This reveals that the majority of the area has high relief and steep sloped. This shows that the watershed is slightly elongated.

\section{Texture ratio $(\mathbf{R t})$}

It is an important factor in the drainage morphometric analysis, which depends upon infiltration capacity and relief aspect of the terrain. It is defined as the ratio between the first order streams and perimeter of the basin $(\mathrm{Rt}=\mathrm{Nl} / \mathrm{P})$. In this study, the texture ratio was 3.42 and is categorized as medium infiltration in nature.

\section{Circulatory ratio $(\mathbf{R c})$}

The circularity ratio $\mathrm{Rc}$ of the basin is the area of a circle having the same circumference as the perimeter of the basin. It is influenced by the stream length and frequency, geology, relief, land use and land cover and climatic condition of the basin. High, medium and low values of $\mathrm{Rc}$ indicate the old, mature, and young stages of the life cycle of the watershed. Miller (1953) has described the basin of the circulatory ratios range 0.4 to 0.5 , which indicates strongly elongated and highly permeable homogenous geologic materials. 
Table.1 Stream order, streams number, stream length, stream length ratio and bifurcation ratios in Katra watershed

\begin{tabular}{|l|l|l|l|l|l|l|l|l|l|l|l|}
\hline Su & Nu & Lu $(\mathbf{m})$ & Lum $(\mathbf{m})$ & Lur & $\begin{array}{l}\text { Lur-r } \\
(\mathbf{m})\end{array}$ & $\begin{array}{l}\text { Lur*Lur-r } \\
(\mathbf{m})\end{array}$ & Luwm & Rb & Nu-r & Rb*Nu-r & Rbwm \\
\hline I & 132 & 70408 & 533 & & & & & 1.63 & & & \\
\hline II & 34 & 23618 & 695 & 1.31 & 166 & 216 & & 3.88 & 166 & 644 \\
\hline III & 7 & 7268 & 1038 & 1.49 & 41 & 61 & & 4.86 & 41 & 199 \\
\hline IV & 1 & 9458 & 9458 & 9.11 & 8 & 73 & 7.00 & 8 & 56 \\
\hline Total & 174 & 110752 & 636 & & 215 & 350 & & 15.74 & 215 & 899 \\
\hline
\end{tabular}

Su: Stream order, Nu: Number of streams, Lu: Stream length, Lum: Mean stream length, Lur: Stream length ratio, Lur-r: Stream length used in the ratio, Luwm: Weighted mean stream length ratio, Rb: Bifurcation ratios, Nu-r: Number of stream used in the ratio, Rbwm: Weighted mean bifurcation ratios

Table.2 Linear morphometric parameters of Katra watershed

\begin{tabular}{|l|l|l|l|l|}
\hline SI. No. & Morphometric parameters & Method/Formula & Reference & Result \\
\hline $\mathbf{1}$ & Main Channel Length (Cl) & GIS Analysis & Length & $12.64 \mathrm{~km}$ \\
\hline $\mathbf{2}$ & Valley Length (Vl) & GIS Analysis & Length & $11.35 \mathrm{~km}$ \\
\hline $\mathbf{3}$ & Channel Index (Ci) & Ci = Cl / Adm (H \& TS) & Miller (1953) & 1.12 \\
\hline $\mathbf{4}$ & Minimum Aerial Distance (Adm) & GIS Analysis & Length & $11.26 \mathrm{~km}$ \\
\hline $\mathbf{5}$ & Valley Index $(\mathrm{Vi})$ & Vi = Vl/ Adm (TS) & Miller (1953) & 1.01 \\
\hline $\mathbf{6}$ & Rho Coefficient $(\rho)$ & $\rho=$ Lur / Rb & Horton (1945) & 1.94 \\
\hline $\mathbf{7}$ & Length from watersheds centre to mouth (Lcm) & GIS Analysis & Black (1972) & $6.45 \mathrm{~km}$ \\
\hline $\mathbf{8}$ & Width of watershed at the centre of mass & GIS Analysis & Black (1972) & $4.86 \mathrm{~km}$ \\
\hline $\mathbf{9}$ & Basin Length $(\mathrm{Lb})$ & GIS Analysis & Schumm $(1956)$ & $11.34 \mathrm{~km}$ \\
\hline
\end{tabular}

Table.3 Areal morphometric parameters of Katra watershed

\begin{tabular}{|c|c|c|c|c|}
\hline Sl. No. & Morphometric parameters & Method/Formula & Reference & Result \\
\hline 1 & Mean Basin Width (Wb) & $\mathrm{Wb}=\mathrm{A} / \mathrm{Lb}$ & Horton (1932) & $2.95 \mathrm{~km}$ \\
\hline 2 & Basin Area (A) & GIS Analysis & Schumm (1956) & $33.52 \mathrm{~km}^{2}$ \\
\hline 3 & Basin Perimeter $(\mathrm{P})$ & GIS Analysis & Schumm (1956) & $38.56 \mathrm{~km}$ \\
\hline 4 & Relative Perimeter (Pr) & $\operatorname{Pr}=\mathrm{A} / \mathrm{P}$ & Schumm (1956) & 0.87 \\
\hline 5 & Length Area Relation (Lar) & $\mathrm{Lar}=1.4 * \mathrm{~A} 0.6$ & Hack (1957) & 11.52 \\
\hline 6 & Lemniscate's (k) & $\mathrm{k}=\mathrm{Lb}^{\wedge} 2 / \mathrm{A}$ & Chorley (1957) & 3.84 \\
\hline 7 & Form Factor Ratio (Rf) & $\mathrm{Ff}=\mathrm{A} / \mathrm{Lb}^{\wedge} 2$ & Horton (1932) & 0.26 \\
\hline 8 & Shape Factor Ratio (Rs) & $\mathrm{Sf}=\mathrm{Lb}^{\wedge} 2 / \mathrm{A}$ & Horton (1945) & 3.84 \\
\hline 9 & Elongation Ratio (Re) & $\mathrm{Re}=2 / \mathrm{Lb} *(\mathrm{~A} / \pi) 0.5$ & Schumm (1956) & 0.58 \\
\hline 10 & Elipticity Index (Ie) & $\mathrm{Ie}=\pi * \mathrm{Vl}^{\wedge} 2 / 4 \mathrm{~A}$ & Schumm (1956) & 3 \\
\hline 11 & Texture Ratio (Rt) & $\mathrm{Rt}=\mathrm{N} 1 / \mathrm{P}$ & Schumm (1956) & 3.42 \\
\hline 12 & Circularity ratio (Rcn) & $\mathrm{Rcn}=\mathrm{A} / \mathrm{P}$ & Strahler (1964) & 0.87 \\
\hline 13 & Circularity Ratio (Rc) & $\mathrm{Rc}=12.57 *(\mathrm{~A} / \mathrm{P} 2)$ & Miller (1953) & 0.28 \\
\hline 14 & Drainage Texture (Dt) & $\mathrm{Dt}=\mathrm{Nu} / \mathrm{P}$ & Horton (1945) & 4.51 \\
\hline 15 & Compactness Coefficient $(\mathrm{Cc})$ & $\mathrm{Cc}=0.2841 * \mathrm{P} / \mathrm{A}^{\wedge} 0.5$ & Gravelius (1914) & 1.89 \\
\hline 16 & Fitness Ratio (Rf) & $\mathrm{Rf}=\mathrm{Cl} / \mathrm{P}$ & Melton (1957) & 0.33 \\
\hline 17 & Wandering Ratio (Rw) & $\mathrm{Rw}=\mathrm{Cl} / \mathrm{Lb}$ & Smart and Surkan (1967) & 1.11 \\
\hline 18 & Watershed Eccentricity $(\tau)$ & $\tau=\left[\left(\left|\mathrm{Lcm}{ }^{\wedge} 2-\mathrm{Wcm}^{\wedge} 2\right|\right)\right]^{\wedge} 0.5 / \mathrm{Wcm}$ & Black (1972) & 0.86 \\
\hline 19 & Hydraulic Sinuosity Index (Hsi) & $\mathrm{Hsi}=((\mathrm{Ci}-\mathrm{Vi}) /(\mathrm{Ci}-1))^{*} 100$ & Mueller (1968) & $93.80 \%$ \\
\hline 20 & Topographic Sinuosity Index (Tsi) & $\mathrm{Tsi}=((\mathrm{Vi}-1) /(\mathrm{Ci}-1))^{*} 100$ & Mueller (1968) & $6.20 \%$ \\
\hline 21 & Standard Sinuosity Index (Ssi) & $\mathrm{Ssi}=\mathrm{Ci} / \mathrm{Vi}$ & Mueller (1968) & 1.11 \\
\hline 22 & $\begin{array}{l}\text { Longest Dimension Parallel to the Principal } \\
\text { Drainage Line (Clp) }\end{array}$ & GIS Analysis & Length & $11.61 \mathrm{~km}$ \\
\hline 23 & Stream Frequency $(\mathrm{Fs})$ & $\mathrm{Fs}=\mathrm{Nu} / \mathrm{A}$ & Horton (1932) & 5.19 \\
\hline 24 & Drainage Density (Dd) & $\mathrm{Dd}=\mathrm{Lu} / \mathrm{A}$ & Horton (1932) & $3.3, \mathrm{~km} / \mathrm{km}^{2}$ \\
\hline 25 & Constant of Channel Maintenance & Unit A/Unit L & Schumm(1956) & $0.30, \mathrm{~km}^{2} / \mathrm{km}$ \\
\hline 26 & Drainage Intensity (Di) & $\mathrm{Di}=\mathrm{Fs} / \mathrm{Dd}$ & Faniran (1968) & 1.57 \\
\hline 27 & Infiltration Number (If) & If $=\mathrm{Fs} * \mathrm{Dd}$ & Faniran (1968) & 17.14 \\
\hline 28 & Length of Overland Flow (Lg) & $\mathrm{Lg}=\mathrm{A} / 2 * \mathrm{Lu}$ & Horton (1945) & $0.15 \mathrm{~km}$ \\
\hline
\end{tabular}


Table.4 Relief related morphometric parameters of Katra watershed

\begin{tabular}{|c|c|c|c|c|}
\hline Sl. No. & Morphometric parameters & Method/Formula & Reference & Result \\
\hline 1 & Height of Basin Mouth (z) & $\begin{array}{l}\text { GIS Analysis / } \\
\text { DEM }\end{array}$ & Height & $817 \mathrm{~m}$ \\
\hline 2 & $\begin{array}{l}\text { Maximum Height of the Basin } \\
\text { (Z) }\end{array}$ & $\begin{array}{l}\text { GIS Analysis / } \\
\text { DEM }\end{array}$ & Height & $1268 \mathrm{~m}$ \\
\hline 3 & Total Basin Relief $(\mathrm{H})$ & $\mathrm{H}=\mathrm{Z}-\mathrm{Z}$ & Strahler (1952) & $451 \mathrm{~m}$ \\
\hline 4 & Relief Ratio (Rhl) & $\mathrm{Rhl}=\mathrm{H} / \mathrm{Lb}$ & $\begin{array}{l}\text { Schumm } \\
(1956)\end{array}$ & 0.04 \\
\hline 5 & Relative Relief Ratio (Rhp) & $\mathrm{Rhp}=\mathrm{H} * 100 / \mathrm{P}$ & Melton (1957) & 1058 \\
\hline 6 & Channel Gradient $(\mathrm{Cg})$ & $\begin{array}{l}\mathrm{Cg}=\mathrm{H} /\left\{(\pi / 2)^{*}\right. \\
\mathrm{Clp}\}\end{array}$ & Broscoe (1959) & $\begin{array}{l}22.37 \\
\mathrm{~m} / \mathrm{km}\end{array}$ \\
\hline 7 & Gradient Ratio (Rg) & $\mathrm{Rg}=(\mathrm{Z}-\mathrm{z}) / \mathrm{Lb}$ & $\begin{array}{l}\text { Sreedevi et al., } \\
(2005)\end{array}$ & 35.96 \\
\hline 8 & Watershed Slope (Sw) & $\mathrm{Sw}=\mathrm{H} / \mathrm{Lb}$ & Degree & 35.96 \\
\hline 9 & Ruggedness Number (Rn) & $\begin{array}{l}\mathrm{Rn}=\mathrm{Dd} *(\mathrm{H} / \\
1000)\end{array}$ & Melton (1957) & 1.35 \\
\hline 10 & $\begin{array}{l}\text { Melton Ruggedness Number } \\
\text { (MRn) }\end{array}$ & $\mathrm{MRn}=\mathrm{H} / \mathrm{A}^{\wedge} 0.5$ & Melton (1965) & 70.47 \\
\hline 11 & Average Slope (S) & $\begin{array}{l}\mathrm{S}=(\mathrm{Z} *(\mathrm{Ct} \mathrm{l} / \mathrm{H})) / \\
(10 * \mathrm{~A})\end{array}$ & $\begin{array}{l}\text { Wenthworth's } \\
\text { (1930) }\end{array}$ & $3.29 \%$ \\
\hline 12 & $\begin{array}{l}\text { Mean Slope of Overall Basin } \\
(\Theta s)\end{array}$ & $\Theta \mathrm{s}=(\mathrm{Ctl} * \mathrm{Cin}) / \mathrm{A}$ & Chorley (1972) & $21.3 \%$ \\
\hline
\end{tabular}

Fig.1 Map showing the drainage line of the study area (Katra watershed)

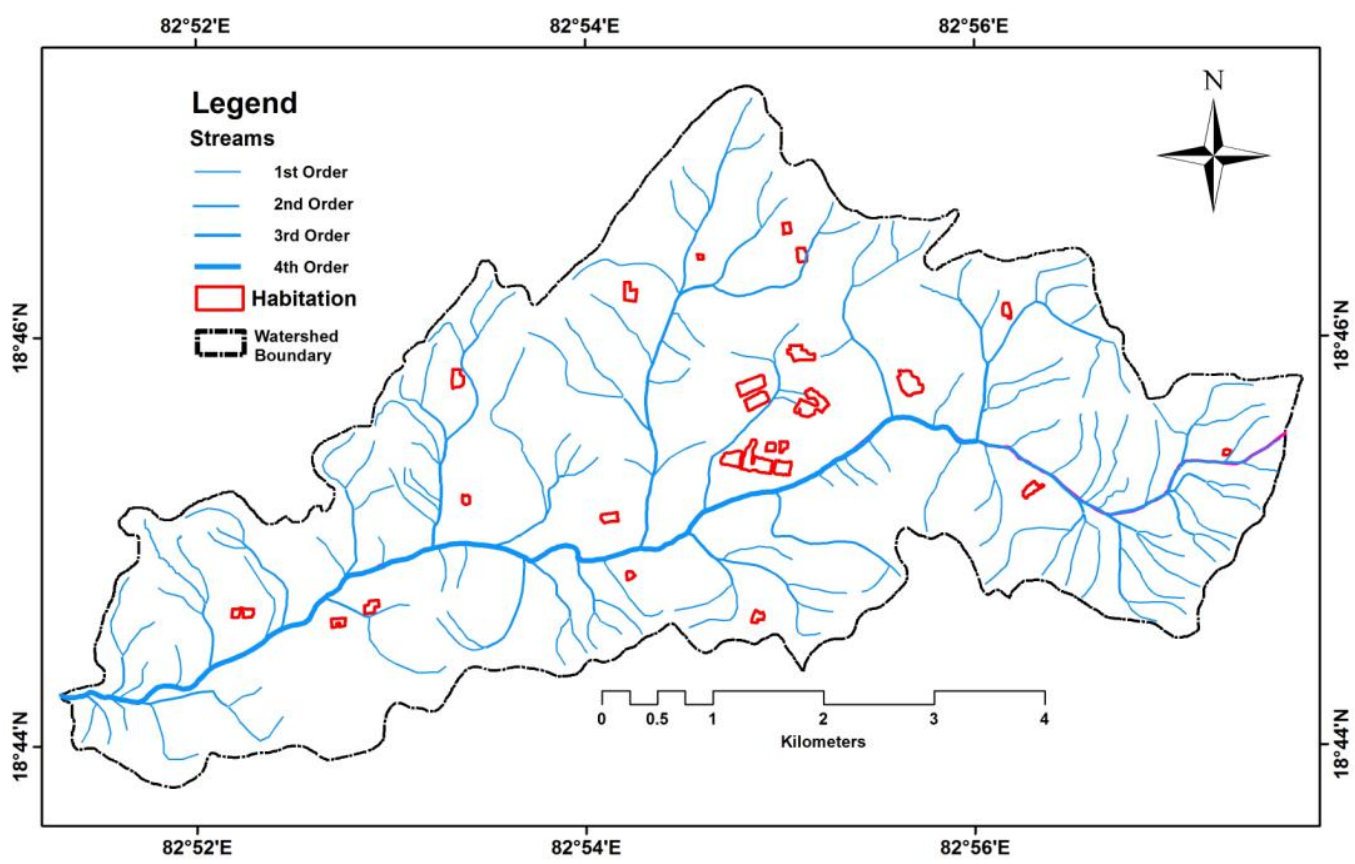


Fig.2 Land use map of the Katra watershed

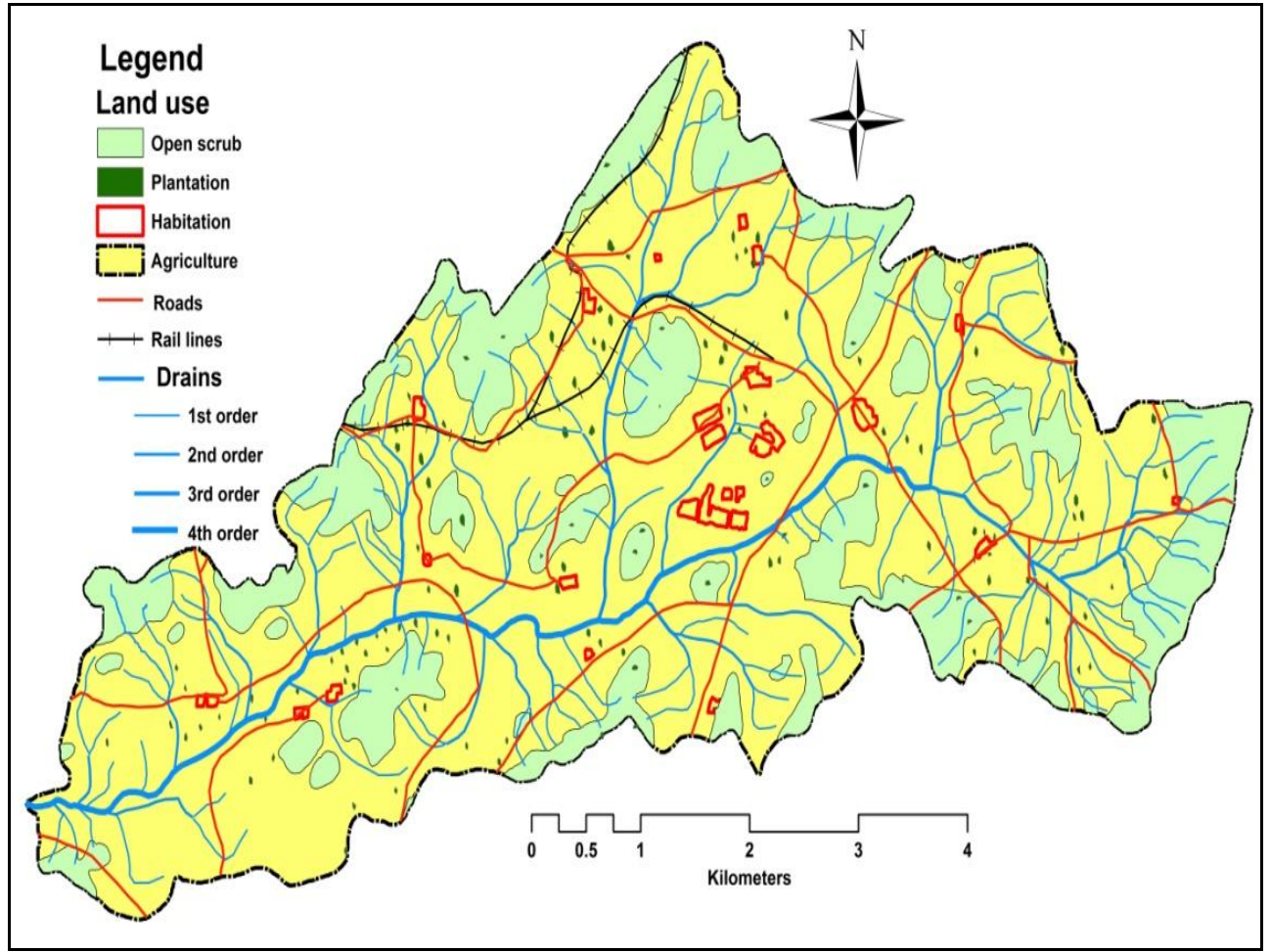

Fig.3 The slope map of Katra watershed

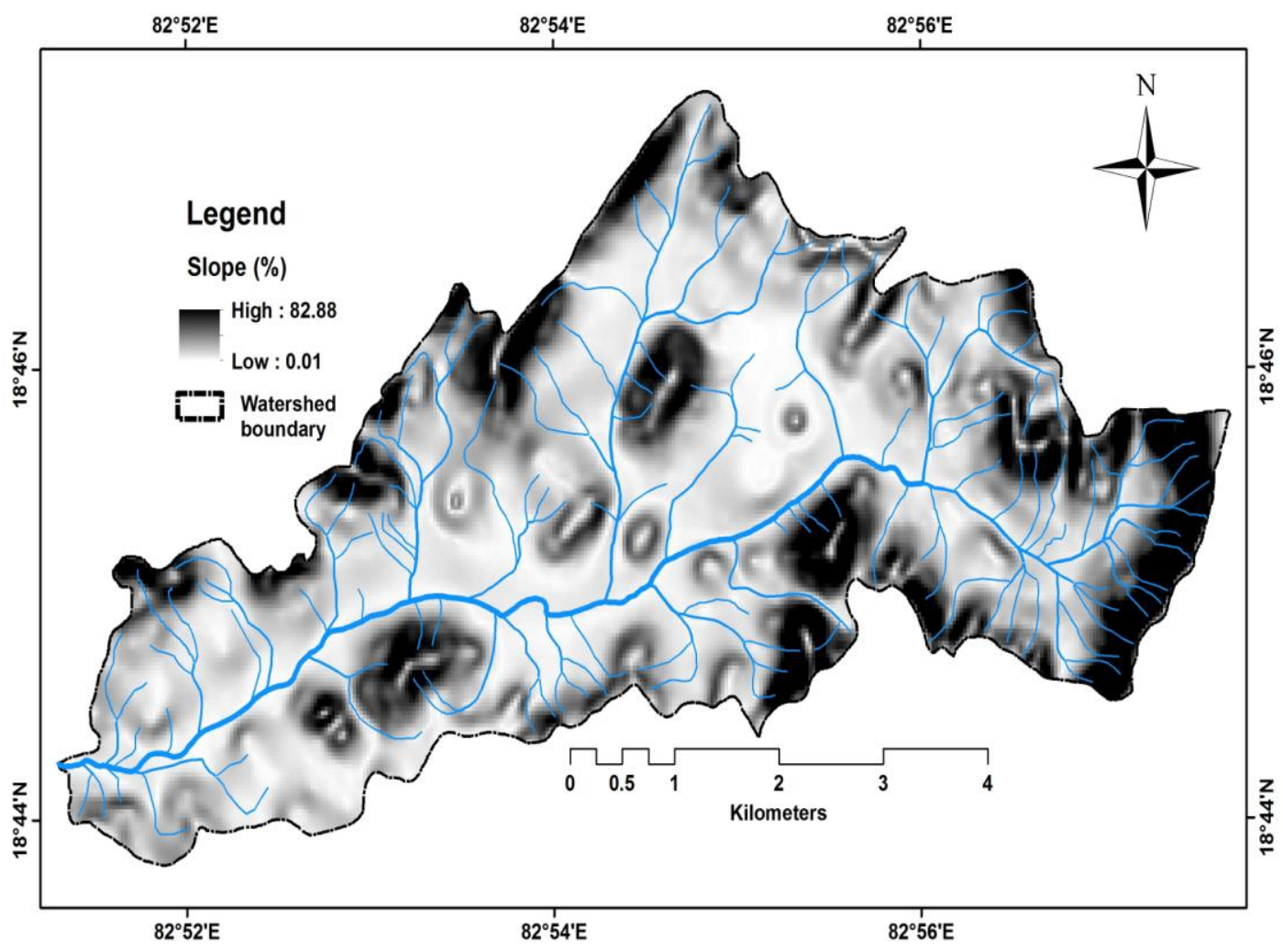


Fig.4 The digital elevation model (DEM) of Katra watershed

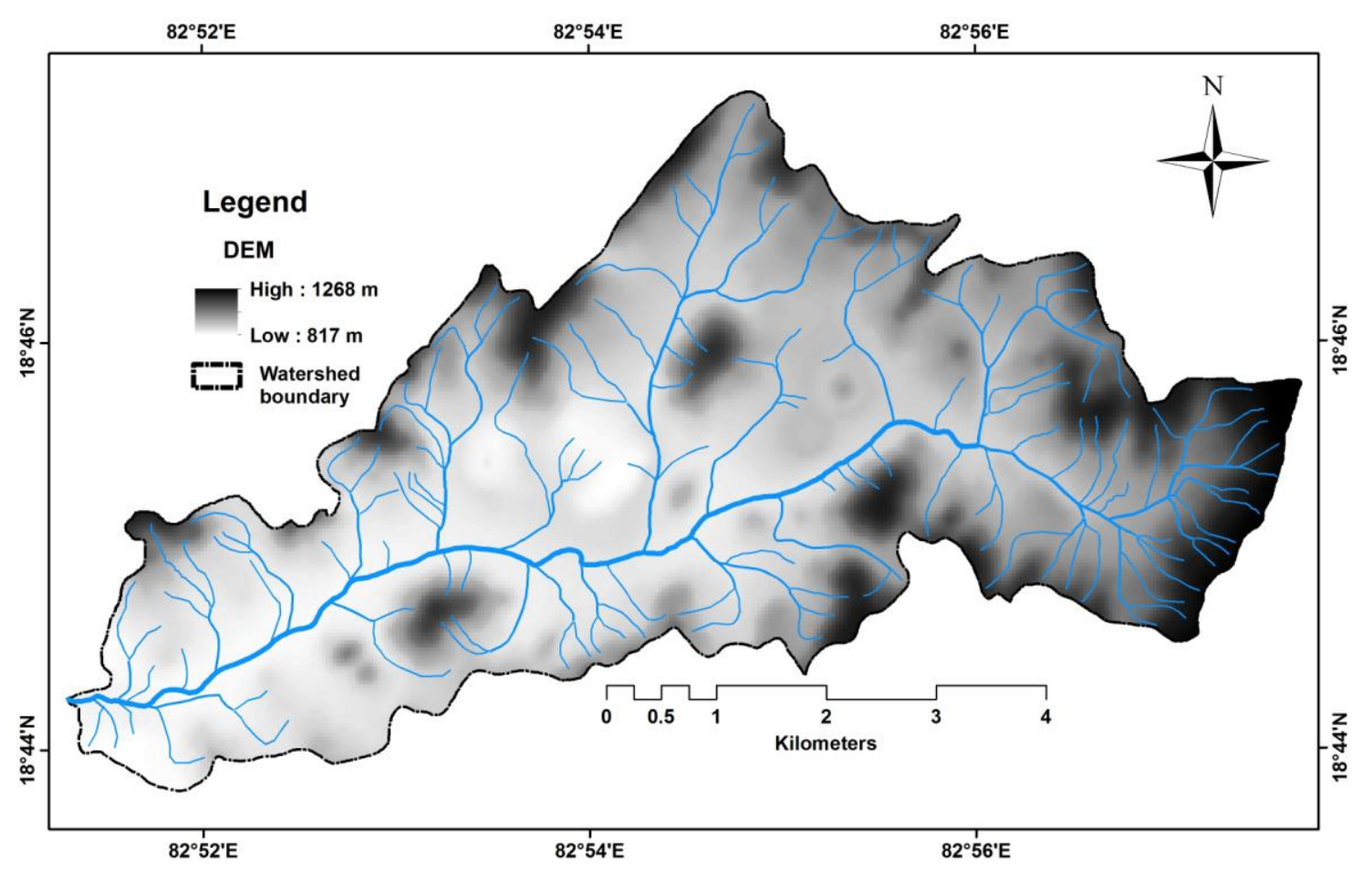

In the present study, the circulatory ratio was 0.28 , indicating slightly elongated watershed with slow runoff discharge and highly permeable subsoil.

\section{Drainage texture (Dt)}

Drainage texture is the total stream number of all orders per perimeter of that area. The drainage texture depends upon vegetation, climate, rock and soil type, infiltration capacity, relief and stage of development.

The drainage texture can be classified into five classes such as very coarse $(<2)$, coarse (2-4), moderate (4-6), fine (6-8), very fine $(>8)$. In the study area, all the sub watersheds have value above 10 which comes under the class very fine drainage texture. The overall value of drainage texture was 4.51. This indicates that the watershed has moderate drainage texture. Similar type of finding was observed by Soni (2016) for Chakrar watershed of Madhya Pradesh.

\section{Compactness coefficient $(\mathrm{Cc})$}

It can be defined as the ratio of perimeter of the watershed to the circumference of circular area, which is equal to the area of the watershed.

It is independent of the size of watershed and dependent only on the slope. It is the deviation of shape of the watershed from a circular watershed. $\mathrm{Cc}=1$ indicates that the basin completely behaves as a circular basin. $\mathrm{Cc}>1$ indicates more deviation from the circular nature of the basin. In the present study the compactness coefficient was 1.89.

\section{Fitness ratio (Rf)}

It can be defined as the ratio of main channel length to the length of the watershed perimeter (Melton, 1957).

It is a measure of topographic fitness. In our present study the fitness ratio was 0.33 . 


\section{Wandering ratio $(\mathbf{R w})$}

It is defined as the ratio of the length of the main stream to the length of the valley (Smart and Surkan, 1967). Valley length is the straight-line distance from the watershed outlet to the farthest point on the ridge. In our study the Wandering Ratio was 1.11.

\section{Watershed eccentricity $(\tau)$}

It is a dimensionless factor (Black 1972). The expression for watershed eccentricity, which is: $\tau=\left[\left(\left|\mathrm{Lcm}^{2}-\mathrm{Wcm}{ }^{2}\right|\right)\right] 0.5 / \mathrm{Wcm}$

Where, $\tau=$ Watershed eccentricity, Lcm $=$ Straight length from the watershed outlet to the centre of gravity of the watershed, and $\mathrm{Wcm}=$ Watershed width at the centre of gravity and perpendicular to $\mathrm{Lcm}$. In our study the Watershed eccentricity was 0.87 .

\section{Centre of gravity of the watershed (Gc)}

It is the channel length measured from the watershed outlet to a point on the stream nearest to the centre of the watershed. The centre of gravity of the watershed was found out by using ArcGIS-9.3 software. In our study the centre of gravity of the watershed is $18^{\circ} 45^{\prime} 35.161^{\prime \prime} \mathrm{N}$ latitude and $82^{\circ} 54^{\prime} 33.805^{\prime \prime} \mathrm{E}$ longitude.

\section{Hydraulic sinousity index (His)}

It is defined as the ratio of channel length to down valley distance. Its value varies from 1 to 4 or more. Streams having a sinuosity of 1.5 are called sinuous streams and above 1.5 are called meandering (Wolman and Miller, 1964). The sinuosity index also deals with various types of sinuosity i.e., topographic and hydraulic sinuosity index concerned with the stream flow and flood plains development. In our study the Hydraulic Sinousity Index was 93.79.

\section{Stream frequency $(\mathbf{F s})$}

The stream frequency (Fs) or channel frequency can be defined as the total number of stream segments of all order per unit area (Horton, 1932). Stream Frequency mainly depends upon the lithology of the basin and the texture of the drainage network. The Stream Frequency of our study was 5.18. This indicates that the increase in stream population is connected to that of drainage density. Similar type of stream frequency was found by Soni (2016) for Chakrar watershed of Madhya Pradesh.

\section{Drainage density (Dd)}

Drainage density is defined as the closeness of spacing of channels (Horton, 1945; Strahler, 1952; Melton, 1965). It is a measure of the total stream length per unit area. Slope gradient and relative relief are the main morphological factor of drainage density. It is an expression to the dissection and analysis of landform, although a function of climate, lithology and relief of the region can finally use as an indirect indicator to explain, those variables as well as the morphogenesis of landform. It was calculated using Spatial Analyst Tool in ArcGIS-9.3. Here in this study area, the drainage density was 3.3 $\mathrm{km} / \mathrm{km}^{2}$ which is an indicative of coarse drainage and permeable sub-surface strata (Strahler, 1964).

Similar type of finding was observed by Soni (2016) for Chakrar watershed of Madhya Pradesh where he found the Dd value of 2.46 $\mathrm{km} / \mathrm{km}^{2}$.

\section{Constant of channel maintenance}

It is the inverse of drainage density as a property to define term constant channel maintenance. It defines the requirement of units of watershed surface to bear one unit of 
channel length. Here in this study area the Constant of Channel Maintenance was 0.30 $\mathrm{km}^{2} / \mathrm{km}$.

\section{Drainage intensity (Di)}

The ratio of the stream frequency to the drainage density is the Di. Here the Drainage Intensity was 1.73. With this low value of drainage density, stream frequency and drainage intensity, runoff is not swiftly removed from the watershed and increases the possibility of water logging and gully erosion.

\section{Infiltration number (If)}

It is the product of drainage density and stream frequency. It gives us an idea about the infiltration characteristics of the watershed. Higher infiltration number means lower infiltration and higher runoff. In Katra watershed the Infiltration Number was 17.14.

\section{Length of overland flow $(\mathrm{Lg})$}

It is the length of water flowing on the ground before entering into the streams (Horton, 1945). Higher is the average slope of the channel lower is the length of overland flow. This factor is quite equal to the length of sheet flow. It is approximately equals to half of reciprocal of drainage density. In the present study the Length of Overland Flow was 0.15 $\mathrm{km}$.

\section{Relief aspects}

\section{Relief ratio $(\mathbf{R r})$}

It is the ratio between maximum relief and horizontal distance along the longest dimension of the watershed. It indicates the overall steepness of a watershed and thereby can identify the erosion intensity of the watershed. $\mathrm{Rr}$ normally increases with decreasing drainage area and size. In the present study the relief ratio was 0.04. Our result is lower than the result obtained by Rai et al., (2014) at Kanhar river basin but higher than the result obtained by Soni (2016) at Chakrar watershed of Madhya Pradesh.

\section{Relative relief (Rrp)}

It is the maximum basin relief which is obtained from the highest point on the watershed perimeter to the mouth of the stream. Relative relief is the difference between highest and lowest elevation in the watershed. The sense of relative relief of any watershed can be got through digital elevation model (DEM) (Fig. 4). Relative relief can be used as an index of the relative velocity of vertical tectonic movements. Relative relief is applied to study reveal active tectonic structures, to recognize palaeo surfaces, to estimate seismic activity, and to study the interaction between endo- and exogenic processes of orogenesis. Here in our study the relative relief of the watershed was $451 \mathrm{~m}$.

\section{Channel gradient $(\mathrm{Cg})$}

The channel gradient was estimated from the contour lines in the topographical sheet. In general, the channel gradient of the $1^{\text {st }}, 2^{\text {nd }}, 3^{\text {rd }}$ and higher order streams varies from 15 to $20^{\circ}, 15$ to $17^{\circ}$, and 20 to $24^{\circ}$, respectively. It helps in determining the downstream increase of discharge which enables the sediment load to be transported on progressively changing slopes and hence the transport capacity. Here in our present study the average value of Channel gradient is $22.37^{\circ}$.

\section{Ruggedness number (Rn)}

It is the product of relief and drainage density. The ruggedness number indicates the terrain structure with relief and drainage density. It also implies that the area is susceptible to soil erosion. The Katra watershed displays the 
ruggedness number as 1.35 (Table 4) and indicate that the area is extremely rugged with high relief and high stream density. Our result is slightly higher than the result obtained by Soni (2016) for a similar type of watershed.

\section{Melton ruggedness number (MRn)}

$\mathrm{MRn}$ is the specialized representation of relief ruggedness within the watershed and alternatively it can be expressed as the slope index (Melton, 1965). In the present study the Melton Ruggedness Number was found to be 70.47 .

\section{Gradient ratio $(\mathbf{R g})$}

It is an indicator of channel slope, which enables assessment of the runoff volume (Sreedevi et al., 2005) Gradient ratio, is an indication of channel slope from which an assessment of the runoff volume could be evaluated. Here in our study area Gradient Ratio was 35.95.

GIS have been proved to be an efficient tool in morphometric analysis of watershed. The morphometric analysis of the drainage networks of watershed reveals the dendritic to sub-dendritic drainage pattern. Slope and topography play the important role for the variation in stream length ratio.

The bifurcation ratio in the Katra watershed is an indication of the negligible influence of geology on the drainage network. The stream frequency and drainage density is positively correlation.

Drainage density is very coarse to coarse textured and the sub-surface strata are somewhat permeable. Low drainage intensity is an indication of water stagnation in the watershed. This study will help the decision makers to devise better water use mechanism for watershed management.

\section{References}

Adhikary, P.P., Madhu, M., Dash, Ch J., Sahoo, D.C., Jakhar, P., Naik, B.S., Hombegowda, H.C., Naik, G.B., Dash, B. 2015. Prioritization of traditional tribal field crops based on RWUE in Koraput district of Odisha. Indian Journal of Traditional Knowledge, 14(1):88-95.

Black, P.E. 1972. Hydrograph responses to geomorphic model watershed characteristics and precipitation variables. Journal of Hydrology, 17:309-329.

Broscoe, A.J. 1959. Quantitative analysis of longitudinal stream profiles of small watersheds. Project No. 389-042, Tech. Bep. 18, Geology Department, Columbian University, ONR, Geography Branch, New York.

Chorley, R.J. 1957. Illustrating the laws of morphometry. Geological Magazine, 94:140-150.

Chorley, R.J. 1972. Spatial analysis in geomorphology. Mathuen and Co. Ltd., London.

Clarke, J.I. 1996. Morphometry from maps: essay in geomorphology. Elsevier Publ., Co., New York, pp 235-274.

Faniran, A. 1968. The index of drainage intensity - a provisional new drainage factor. Australian Journal of Science, 31:328-330.

Friend, P.F., Sinha, R. 1993. Braiding and meandering parameters. In: Best JL, Bristow CS (Eds.), Braided Rivers, vol. 75. Geological Society Special Publication, London, pp. $105-111$.

Hack, J.T. 1957. Studies of longitudinal stream profiles in Virginia and Maryland. U.S. Geol. Survey Prof., Paper 294-B.

Horton, R.E. 1932. Drainage basin characteristics. Transaction Americam Geophysical Union, 13:350-61. 
Horton, R.E. 1945. Erosional development of streams and their drainage basins. Geological Society of America Bulletin, 56:275-370.

Magesh, N.S., Chandrasekar, N. 2012. GIS model-based morphometric evaluation of Tamiraparani subbasin, Tirunelveli district, Tamil Nadu, India. Arabian Journal of Geosciences, doi: 10.1007/s12517-012-0742-z.

Magesh, N.S., Chandrasekar, N., Soundranayagam, J.P. 2011. Morphometric evaluation of Papanasam and Manimuthar watersheds, parts of Western Ghats, Tirunelveli district, Tamil Nadu, India: a GIS approach. Environmental Earth Science, 64:373381.

Magesh, N.S., Jitheshlal, K.V., Chandrasekar, N., Jini, K.V. 2013. Geographical information system-based morphometric analysis of Bharathapuzha river basin, Kerala, India. Applied Water Science, 3:467477.

Melton, M.A. 1957. An analysis of the relation among elements of climate, surface properties, and geomorphology. Department of Geology, Columbia University, New York, USA.

Melton, M.A. 1965. The geomorphic and paleoclimatic significance of alluvial deposits in Southern Arizona. Journal of Geology, 73:1-38.

Mesa, L.M. 2006. Morphometric analysis of a subtropical Andean basin (Tucuman, Argentina). Journal of Environmental Geology, 50(8):1235-1242.

Miller, V.C. 1953. A quantitative geomorphologic study of drainage basin characteristics in the Clinch Mountain area, Virginia and Tennessee, Project NR 389042, Tech Rept 3, Columbia University Department of Geology, ONR Geography Branch, New York.
Mueller, J.E. 1968. An introduction to the hydraulic and topographic sinuosity indexes. Annals of the American Association of Geographers, 58(2):371385.

Pande, C.B., Moharir, K. 2015. GIS based quantitative morphometric analysis and its consequences: a case study from Shanur River Basin, Maharashtra India. Applied Water Science, DOI 10.1007/s13201-015-0298-7

Pankaj, A., Kumar, P. 2009. GIS based morphometric analysis of five major sub-watersheds of Song river, Dehradun district, Uttarakhand with special reference to landslide incidences. Journal of Indian Society of Remote Sensing, 37:157-166.

Pareta, K., Pareta, U. 2011. Quantitative morphometric analysis of a watershed of Yamuna basin, india using ASTER (DEM) data and GIS. International Journal of Geomatics and Geosciences, 2(1):248-269.

Rai, P.K., Mohan, K., Mishra, S., Ahmad, A., Mishra, V.N. 2014. A GIS-based approach in drainage morphometric analysis of Kanhar river basin, India. Applied Water Science, DOI 10.1007/s13201-014-0238-y.

Rudraiah, M., Govindaiah, S., Srinivas, V.S. 2008. Morphometry using remote sensing and GIS techniques in the subbasins of Kagna river basin, Gulburga district, Karnataka, India. Journal of Indian Society of Remote Sensing, 36:351-360

Schumn, S.A. 1956. Evolution of drainage systems and slopes in badlands at Perth Anboy, New Jersey. Geological Society of America Bulletin, 67:597-646.

Smart, S., Surkan, A.J. 1967. The relationship between mainstream length and area in drainage basins. Water Resources Research, 3:963-973. 
Soni, S. 2016. Assessment of morphometric characteristics of Chakrar watershed in Madhya Pradesh India using geospatial technique. Applied Water Science, DOI 10.1007/s13201-016-0395-2.

Sreedevi, P.D., Owais, S., Khan, H.H., Ahmed, S. 2009. Morphometric Analysis of a watershed of south India using SRTM data and GIS. Journal of Geological Society of India, 73:543552.

Sreedevi, P.D., Subrahmanyam, K., Shakeel, A. 2005. The significance of morphometric analysis for obtaining groundwater potential zones in a structurally controlled terrain. Journal of Environmental Geology, 47(3):412420.

Strahler, A.N. 1952. Hypsometric analysis of erosional topography. Geological Society of America Bulletin, 63:111742.

Strahler, A.N. 1957. Quantitative analysis of watershed geomorphology.
Transactions American Geophysical Union, 38:913-920.

Strahler, A.N. 1964. Quantitative geomorphology of drainage basin and channel network. Handbook of Applied Hydrology, McGraw Hill Book Company, New York, pp 39-76.

Wentworth, C.K. 1930. A simplified method of determining the average slope of land surfaces. American Journal of Science, 21:184-194.

Wilson, J.S., Chandrasekar, N., Magesh, N.S. 2012. Morphometric analysis of major sub-watersheds in Aiyar and Karai Pottanar Basin, Central Tamil Nadu, India using remote sensing and GIS techniques. Bonfring International Journal of Industrial Engineering and Management Science, 2(1):8-15.

Wolman, M.G., Miller, J.P. 1964. Magnitude and frequency of forces in geomorphic processes. Journal of Geology, 68(1):54-74.

\section{How to cite this article:}

Partha Pratim Adhikary and Jyotiprava Dash Ch. 2018. Morphometric Analysis of Katra Watershed of Eastern Ghats: A GIS Approach. Int.J.Curr.Microbiol.App.Sci. 7(03): 1651-1665. doi: https://doi.org/10.20546/ijcmas.2018.703.198 